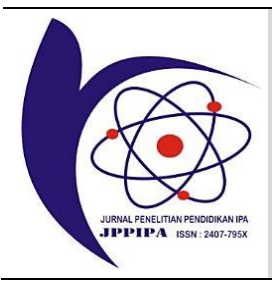

\title{
Analysis of Validation Development Science Learning Tools using Guided Inquiry Model Assisted by Real Media to Improve the Understanding Concepts and Science Process Skills of Students
}

\author{
Susilawati $12^{\star}$, Aris Doyan ${ }^{1,2^{*}}$, Putu Artayasa ${ }^{2}$, Hary Soeprianto ${ }^{2}$, Ahmad Harjono ${ }^{1,2}$ \\ 1Physics Education, Faculty of Teacher Training and Education, University of Mataram, Lombok, West Nusa Tenggara, Indonesia. \\ ${ }^{2}$ Master of Science Education Program, University of Mataram, Lombok, West Nusa Tenggara, Indonesia.
}

DOI: $10.29303 /$ jppipa.v7i1.473

\section{Article Info}

Received: September $2^{\text {th }}, 2020$

Revised: December $10^{\text {th }}, 2020$

Accepted: December 18th, 2020

\begin{abstract}
Development of natural science learning tools with guided inquiry model assisted by real media to improve students' mastery of science process concepts and skills has been successfully carried out. The purpose of this development is to produce a science learning tool guided Inquiry model assisted by valid real media. The development of these tools uses the 4D model (define, design, develop, and disseminate). Science learning tools developed in the form of syllabus, lesson plan implementation, student worksheets, science process skills instruments, and students' mastery of concepts. The results showed that the device validation process developed with the guided inquiry learning model fulfilled the content validation and construct validation. This suggests that it has produced a very valid device.
\end{abstract}

Keywords: Validation analysis; guided inquiry model; real media; natural science learning tools; concept mastery; science process skills.

Citation: $\quad$ Susilawati, S., Doyan, A., Artayasa, P., Soeprianto, H., \& Harjono, A. (2020). Analysis of Validation Development Science Learning Tools using Guided Inquiry Model Assisted by Real Media to Improve the Understanding Concepts and Science Process Skills of Students. Jurnal Penelitian Pendidikan IPA, 7(1), 41-44. doi:https://doi.org/10.29303/jppipa.v7i1.473

\section{Introduction}

Natural Science is a science that consists of several branches of science including physics, chemistry, and biology. The concepts and theories in science are obtained through an experiment or experiment which is carried out based on scientific procedures.

Natural Science is a process of discovery that is carried out systematically about nature. The development of competencies and the process of understanding the natural surroundings are emphasized in science learning. To obtain a deeper understanding of the natural surroundings, the process of inquiry and action is directed at Science Education (Trianto, 2012).

Essentially science learning is a product, process, and application of knowledge. Science as a product includes facts, concepts, principles, and theories, while a process includes the skills and attitudes that must be possessed to obtain a product. These skills are known as process skills, while the attitudes that must be possessed are called scientific attitudes. Students must be active in conducting experiments to find the truth of the concepts they are learning by not forgetting the scientific attitude like a researcher. However, the reality in the field of science learning is still informative, so it makes students learn science material by memorizing it. Students are only given a direct understanding of the 
material so that students tend not to understand the material they are learning more deeply. An in-depth understanding of the material is very important in the process of honing students' conceptual mastery skills. The science learning that occurs must be able to change the old paradigm from teacher-centered to studentcentered. Learning science is said to be successful if students have mastered science material cognitively, psychomotor, and affective. One way to involve students to be active so that they can understand the concept of science well is by applying a guided inquiry model (Susilawati et al, 2015; Istiqomah et al, 2016).

The guided inquiry learning model is a learning model that actually places students as learning subjects so that students can learn more independently and the knowledge obtained from their thoughts will be easier to remember (Susilawati et al, 2019). In addition, in this model students are allowed to find and find their own answers to the problems given by their own observations and experiences (Susilawati et al, 2019).

This study focuses on developing science learning tools based on guided inquiry learning models with real media to measure the mastery of science process concepts and skills in junior high schools (Jamuri et al, 2015).

\section{Method}

This research is development research with a $4 \mathrm{D}$ model. The $4 \mathrm{D}$ model includes several stages, namely define, design, develop, and disseminate. This research is limited to the development stage, which includes the validity test. The data obtained from the validity test were taken from the results of reviewers and assessments of content aspects and learning activities by five expert validators. The initial products developed were in the form of syllabus, learning implementation plans, Dididk Participant Worksheets, instruments that consist of mastery of concepts and skills science process learners. The data obtained in this study were analyzed using equation 1 :

$$
V=\frac{\text { average value of expert validity }}{\text { maximum score }}
$$

The level of validity can be determined based on the following table 1 :

Table 1. Criteria for Evaluation Results for Assessment Instruments (Arikunto, 2010).

\begin{tabular}{ll}
\hline Value Average & Category \\
\hline $4.2 \geq \mathrm{SV} \leq 5.0$ & Very Valid \\
$3.4 \geq \mathrm{SV} \leq 4.2$ & Valid \\
$2.6 \geq \mathrm{SV} \leq 3.4$ & Valid Enough \\
$1.8 \geq \mathrm{SV} \leq 2.6$ & Invalid \\
$1.0 \geq \mathrm{SV} \leq 1.8$ & Very Invalid \\
\hline
\end{tabular}

\section{Result and Discussion}

The Define Stage

The define stage includes problem and curriculum analysis. The purpose of the problem analysis is to find out the problems experienced by students, including their characteristics. Based on the results of the characteristic analysis of students, it was found that generally, class VIII had an age of 13 to 14 years. The results of the 2013 curriculum analysis showed basic competencies of 3.12 and 4.12 regarding Light and Optical Devices. Based on these basic competencies, indicators and learning objectives to be achieved by students can be developed.

\section{The Design Stage}

The second stage is design, where at this stage the researcher designs learning tools, validation sheets, and student response questionnaires. As for designing validation sheets and student response questionnaires, there are several components of the syllabus, learning implementation plans, and developed student worksheets. The syllabus components that have been developed consist of the identity and format of the syllabus matrix. Whereas for the learning implementation plan being developed is the school identity; subjects; class; subject matter and time allocation; basic competence and competency achievement indicators; learning objectives; learning materials; method; learning media and learning resources; steps of learning activities and assessment of learning outcomes. Student worksheets consist of the title of learning material, student identity, time, supporting pictures, learning objectives, and instructions.

The validation sheet for the concept mastery instrument is designed based on several aspects, namely material, language, and test construction. Validation sheets for students' science process skills instruments include the suitability of questions with indicators; construction and Language. test validation, reliability, level of difficulty, and distinguishing power of the questions were carried out to determine whether the questions made were good.

\section{The Development Stage}

The development stage aims to produce the final form of science learning tools with guided inquiry models assisted by real media. The stage consists of two steps, namely expert judgment and development trials. The products developed in this study have a characteristic that is learning activities that follow the steps of guided inquiry learning model activities. The finished learning device was then tested for validity by five expert validators. 
Based on Table 2, it can be seen that the science learning device with the guided inquiry model assisted by real media developed has an average value above 4.2. This shows that the device that has been developed is very valid. If it meets the criteria for content validity and construct validity, the learning device is said to be valid (Kartini et al, 2019). Devices that have a very valid category can be used as research material (Khasanah et al, 2019). Suggestions and revised results from expert validators can be shown in Table 3 .

Table 2. The results of the validation of science learning tools with guided inquiry models assisted by real media

\begin{tabular}{|c|c|c|c|c|c|c|c|c|c|}
\hline \multirow{2}{*}{ No } & \multirow{2}{*}{ Learning Devices } & \multicolumn{5}{|c|}{ Average validator score } & \multirow{2}{*}{-Total } & \multirow{2}{*}{ Average } & \multirow[b]{2}{*}{ Category } \\
\hline & & $\mathrm{V}_{1}$ & $\mathrm{~V}_{2}$ & $\mathrm{~V}_{3}$ & $\mathrm{~V}_{4}$ & $\mathrm{~V}_{5}$ & & & \\
\hline 1 & Syllabus & 4.67 & 4.11 & 4.52 & 4.77 & 4.65 & 22.72 & 4.54 & Very Valid \\
\hline 2 & Lesson Plan (LP) & 4.33 & 4.63 & 4.53 & 4.35 & 4.53 & 22.37 & 4.47 & Very Valid \\
\hline 3 & Student Activity Sheet (SAS) & 3.98 & 4.80 & 4.45 & 4.57 & 4.75 & 22.55 & 4.51 & Very Valid \\
\hline 4 & Concept mastery test instrument & 4.57 & 4.25 & 4.44 & 4.64 & 4.56 & 22.46 & 4.49 & Very Valid \\
\hline 5 & Science process skill test instrument & 4.33 & 4.17 & 4.65 & 4.55 & 4.47 & 22.17 & 4.43 & Very Valid \\
\hline
\end{tabular}

Table 3. Suggestions and revisions from the Expert Validator

\begin{tabular}{|c|c|c|}
\hline No & Suggestion & Revision \\
\hline \multirow[t]{4}{*}{1} & Syllabus & \\
\hline & Error writing the word Science & - Writing the word Ipa into science \\
\hline & $\begin{array}{l}\text { Writing the words in the syllabus there are still errors so it } \\
\text { still needs to be corrected }\end{array}$ & $\begin{array}{l}\text { - Writing of several words in the syllabus has been } \\
\text { improved }\end{array}$ \\
\hline & $\begin{array}{l}\text { The question of mastering the concepts contained in the } \\
\text { syllabus is only a matter of description, even though the } \\
\text { appendix is also a multiple-choice question }\end{array}$ & $\begin{array}{l}\text { - In the syllabus, it has been improved that the } \\
\text { concept mastery is in the form of multiple-choice } \\
\text { questions }\end{array}$ \\
\hline
\end{tabular}

2 Lesson Plan (LP)

- The description of the subject matter, especially in the - Has added a description of the subject matter to the lesson plan is too short, it is necessary to add a description lesson plan especially about the breakdown of facts of facts from everyday life about the properties of light from daily life about the properties of light (propagating straight and reflected) and a description of the (propagating straight and reflected) and a use of flat, convex, and concave mirrors in everyday life. description of the use of flat, convex, and concave mirrors in everyday life.

- Indicators in the lesson plan are still dominated by aspects - Indicators on the lesson plan have been added to of knowledge, and still little writing on aspects of attitudes and skills. Indicators of skills aspects in the lesson plan in the form of conducting experiments and presentations can be added with indicators designing experiments, calculating, drawing, or graphing and concluding. aspects of attitude and skills. Indicators of skills aspects to the lesson plan have been added in the form of conducting experiments and presentations with indicators designing experiments, calculating, drawing, or graphing and concluding.

- The description or formulation of learning objectives is still - Description or formulation of learning objectives has incomplete, there are still many learning objectives that do not include aspects of $C$ (condition) and D (Degree). been added to the learning objectives that include aspects of $\mathrm{C}$ (condition) and $\mathrm{D}$ (Degree).

- Examples of facts on learning material in the lesson plan - Examples of facts on learning material in the lesson need to be added. plan have been added.

- Learning resources written in the lesson plan are limited to - Learning resources written in the lesson plan have books so other learning resources need to be added such as pictures, concept maps, magazines, science comics, or short reads that teenagers like.

3 Student Activity Sheet (SAS)

- Subject identity and time allocation need to be written on - Subject identity and time allocation were added to the the SAS. SAS

- Indicators on the second Basic Competencies (aspects of - Indicators on the second Basic Competencies (skills skills) have not been written on the SAS aspect) have been added to the SAS.

- Aspect D (degree) has not been explicitly written on the - Aspect D (degree) has been written on the learning learning objectives in SAS objectives in SAS

- The material and methods are good.

- A variety of learning resources need to be added

- The material and methods are good.

- A variety of learning resources have been added 
- The steps of activities in SAS need to be adjusted to the guided inquiry learning model that is to provide opportunities for students to plan investigative activities.

$4 \quad$ Instrument of Science Process Skill

- Need to add an important aspect of the science process skills, namely the science process, which is about writing experimental results in the form of tables or graphs and summarizing experimental data.

- Scores on the science process skills assessment rubric should be sorted from smallest to largest.

- Need to add an important aspect of the science process skills, namely the science process, which is about writing experimental results in the form of tables or graphs and summarizing experimental data.
The steps of the activities in SAS have been adjusted to the guided inquiry learning model that is to provide opportunities for students to plan investigative activities.

Has added an important aspect of the science process skills, namely the science process, which is about writing experimental results in the form of tables or graphs and inferring experimental data.

- The scores on the science process skills assessment rubric have been sorted from the smallest to the largest.

Has added aspects of the science process skills, namely the science process, which is about writing experimental results in the form of tables or graphs and summarizing experimental data.

\section{Conclusion}

The whole discussion above shows that the process of validating the device developed with the guided inquiry learning model fulfills the content validation and construct validation. This suggests that it has produced a very valid device.

\section{Acknowledgements}

Thank you to the Dean of FKIP, the Head of the Department of PMIPA and the Chair of the Physics Education Study Program and the headmaster of Mataram 2 Public High School so that this research can be carried out well.

\section{References}

Arikunto, S. (2012). Dasar-Dasar Evaluasi Pendidikan Edisi 2. Jakarta: Bumi Aksara.

Istiqamah, N., Doyan, A., \& Taufik, M. (2016). Pengaruh Model Pembelajaran Discovery dan Inkuiri Terbimbing Berbasis Eksperimen Terhadap Hasil Belajar Fisika dan Sikap Ilmiah Siswa. Jurnal Penelitian Pendidikan IPA, 2(1), 2738, doi: 10.29303/jppipa.v2i1.30.

Jamuri, Kosim, \& Doyan, A. (2015). Pengaruh Model Pembelajaran Kooperatif STAD Berbasis Multi Media Interaktif Terhadap Penguasaan Konsep Siswa pada Materi Termodinamika. Jurnal Penelitian Pendidikan IPA, 1(1), 123-134. doi:10.29303/jppipa.v1i1.11.

Kartini, Doyan, A., Kosim, Susilawati, Khasanah, B.U., Hakim, S., \& Muliyadi, L. (2019). Analysis of Validation Development Learning Model Attainment Concept to Improve Critical Thinking Skills and Student Learning Outcomes.
Jurnal Penelitian Pendidikan IPA, 5(2), 185-188. doi: 10.29303/jppipa.v5i2.262.

Khasanah, B. U., Doyan, A., Gunawan, Susilawati, Kartini, Hakim, S., \& Muliyadi, L., (2019). Analysis Validation of Learning Media Quantum Phenomenon. Jurnal Penelitian Pendidikan IPA, 5(2), 189-193. doi: 10.29303/jppipa.v5i2.265.

Susilawati, Susilawati, \& Sridana, N. (2015). Pengaruh Model Pembelajaran Inkuiri Terbimbing Terhadap Keterampilan Proses Sains Siswa. Jurnal Tadris IPA Biologi FITK IAIN Mataram, 8(1), 27-36.

Susilawati, Doyan, A., Harjono, A. \& Kosim. (2019). Penerapan Model Pembelajaran Inkuiri Berbasis Media Virtual Program Java Pada Guru Fisika Dan Siswa SMA. Jurnal Pengabdian Masyarakat Sains Indonesia, 1(1), 4-10.

Susilawati, Doyan, A., \& Ayub, S. (2019). Perbedaan Keterampilan Generik Sains antara Model Pembelajaran Berbasis Masalah dengan Inkuiri Terbimbing Ditinjau dari Kemampuan Berpikir Kritis Siswa SMA. Jurnal Pendidikan Fisika dan Teknologi, 5 (1), 16-24. doi:10.29303/jpft.v5i1.887.

Susilawati, Doyan, A., Artayasa, P., Soeprianto, H., Harjono, A. \& Kartini. (2019). Effectiveness of Scientific Learning Guided Inquiry Devices Based on Real Media to Improve Understand Concept and Skills Process of Science Students. The $2^{\text {nd }}$ International Conference on Elementary Education, 2 (1), 517-524.

Trianto. (2012). Model Pembelajaran Terpadu dalam Teori dan Praktek. Jakarta : Prestasi Pustaka Publisher. 